\title{
Inscriptions on the Iberian Peninsula: Material Script and Narrative Logic in Castilian and Catalan Literatures
}

\section{Introduction: Iberian Literatures and Narrativity}

Before the unification of the Castilian and the Aragonés crowns under the "Catholic Kings" Ferdinand II of Aragon and Isabella I of Castile in 1479, the medieval Iberian Peninsula was a heterogeneous mosaic of smaller kingdoms. This linguistic diversity has not changed significantly until today. The Iberian primary dialects català, gallego, old castellano, (navarro-)aragonés and astur-leonés (the latter three combining into Castilian) all developed from vernacular Latin. While Castilian ${ }^{1}$ and Catalan ${ }^{2}$ evolved into important juridical and administrative languages after political unification campaigns during the thirteenth and fourteenth centuries, Gallego-Portuguese was prized as the language of poetry (cantigas) and was, as such, also used by Castilian writers. ${ }^{3}$ Nevertheless, each of the three dominant romances (vernacular languages) developed a sophisticated literary register and rich textual corpora. If the bureaucratic structures set up for the rivalries between the royal houses and the campaigns against the Muslim domination were great motors for the rise of vernacular cultural expression,

\footnotetext{
1 For a short linguistic overview, see Cichon 2012, 3-7. Due to the expansion of the Castilian dialect during the Reconquista and Repoblación campaigns, this variety could already substitute Latin in administration, historiography and laws during the thirteenth century under the Crown of Fernando III and Alfonso X, cf. Cichon 2012, 5. See also Penny 1991. While Eberenz 1991 distinguishes the period between 1450 and 1650 as a "middle"-Spanish variety, Cano Aguilar marks the beginning of a linguistic register "of the Austrias" in 1475 (2004, 659). In his influent study El Español a través de los tiempos, Cano Aguilar observes a "fundamental variation in the fifteenth century" $\left(1992^{2}, 219\right)$, but includes this century into the "Castellano Medieval."

2 Old Catalan develops as a proper vernacular language (linguistically close to Occitan) in the territory of the Principado de Catalunya, the Valencian Kingdom, the Balearic Islands and Sardinia. For the evolution of medieval Catalan, see Rabella 2012. Like Castilian, Catalan also founded its linguistic hegemony by a political and administrative expansion. From the twelfth to the fourteenth centuries, the Crown of Aragón increased the efforts of a royal "scriptural" administration, see Gimeno Blay 2006 and Aurell 2012.

3 Symptomatic is, for example, the fact that Alfonso X signs both the Castilian Historiography Estoria general and a poetic cycle of Gallego-Portuguese religious songs (Cantigas de Santa María).

This publication originated in the Collaborative Research Centre 933 "Material Text Cultures. Materiality and Presence of Writing in Non-Typographic Societies" (subproject C09 “Inscription of the Body: Text and Body in Pre-modern Iberian Literature"). The CRC 933 is funded by the German Research Foundation (DFG).
}

๑ Open Access. () 2019 Stephanie Béreiziat-Lang, published by De Gruyter. (c) BY-NC-ND This work is licensed under the Creative Commons Attribution-NonCommercial-NoDerivatives 4.0 License. 
the influence of the Arabian cultural world and the rediscovery of classical Antiquity also boosted literary production. Each romance developed its own textual corpus, so that many texts circulated as parallel variants, permitting cultural and sometimes political differentiations. One striking example of this phenomenon are historiographic texts, where the resemantization of political facts indicates dynastic power plays. ${ }^{4}$

For this short and necessarily eclectic overview of inscribed objects in medieval narrative, I will focus on the literary productions in Castilian and Catalan. While Gallego-Portuguese texts also offer interesting inscriptions, I leave them aside for the sake of coherence. My understanding of "narrative" is rather broad, due to challenges of distinguishing between pre-modern literary genres and an uncertain notion of "literature" altogether. ${ }^{5}$ In the Iberian context, not only literary prose like the Arthurian romances, but also historiographical texts, and even philosophical or theological treatises, contain narrative elements and recall the structure of successive adventures. Finally, although the notion of narrativity is of course not limited to prose, I will also exclude verse compositions, smaller poetry forms and theatre here.

Narrated inscriptions have not been a separate focus in previous scholarship on Iberian literatures. While occasional instances of non-standard material writing in different literary genres and time periods have been covered, a genre- and language-crossing approach is still lacking. ${ }^{6}$ The appearance of text-bearing clothing in the Castilian courtly and chivalric novel since the fifteenth century, for example, has been related to historical tournament practices, but has not been linked to fictional representations of inscribed bodies in mystic or magical contexts. Likewise, it is both interesting and necessary to examine historical practices of reading and text-production in relation to the presence of writing in fictional contexts in order to clarify the scope of the phenomena of inscriptions, writing and hermeneutics. In relation to the presence of prior non-human (magic, divine) writing within the fictional world, the problematic of a fictional modelling of the marvellous or a specific pre-modern phantastic is also of interest. This article aims to juxtapose some of those different facets of narrated inscriptions, showing some leads for further comparative readings.

A quantitative approach to narrated inscriptions shows a clear rise in the phenomenon in the fifteenth century. ${ }^{7}$ This might be due to the increasing relevance and

4 See the variants of the fourteenth-century Spanish and Portuguese Crónicas. For the example of the Portuguese king Afonso Henriques, see Videira Lopes 2005.

5 For the problem of narrativity, see White 1981.

6 For the appearance of magic writing in chivalric romances, or the practice of text-bearing vestment in courtly contexts, see section 4 and 5 of this article.

7 This approach involves selective database research: key-word searches related to the semantic field of writing and inscription on the one hand (letters, verbal forms of "to write"), and material supports for writing and potentially text-bearing artefacts on the other (arms, textiles, body parts etc.) (see also Iris Roebling-Grau's and Sascha A. Schultz' article on Old French in this volume). For Spanish texts, searching in the CORDE database of Real Academia Española, Corpus diacrónico del español, http:// www.rae.es (last accessed: 30.05.2019), with around 250 millions of registers. The Gallego-Portuguese 
everyday presence of writing, but could also result from the growing importance of allegory and emblematics as visual representations of abstract meaning. The reduction of complex genealogical, relational or individual attributions to pictograms or short textual mottos in the historical world (for example, in the tournament practices at the time) provided models for similar inscriptions in fictional worlds. Vice versa, the impact of fictional models for the representation of power also influenced "real-life" strategies. Finally, the rise of narrated inscriptions in the Iberian corpus during the fifteenth century is also related to the increasing influence of foreign literatures and cultures in this period. For example, most of the recorded Iberian adaptions of Arthurian texts only date back to the fifteenth century. Unlike earlier indigenous Hispanic epic texts and chronicles, the fifteenth-century Crónicas particulares and especially the chivalric romance (novella caballeresca / libro de caballerias) and the courtly sentimental romance (novela sentimental) prominently feature textuality, as letters, forms of diegetic mise en abyme and various forms of material inscriptions.

\section{Before 1400: Narrated Inscriptions as Markers of Otherness}

Before 1400, narrated inscription is not much of a concern in literary texts. In the famous Castilian verse epic Cantar de Mio Cid (c.1200) or the royal chronicles of the Kings Jaume I (c. 1250) and Pere III (c.1380), scenes involving writing are limited to a more or less marginal exchange of letters or the presence of administrative documents. ${ }^{8}$ Writing on materials other than parchment or paper does not feature. Epitaphs in stone fulfil a merely documentary function. ${ }^{9}$ Inscriptions on other architectural elements appear preferentially in the context of a remote (mythical) past. They function as a fictional ekphrasis of an imaginary otherworld different from the one in which the literary characters live. Material writing appears in the Sumas de la historia troyana de Leomarte (1350) and also in the first chapters of General Estoria or the Crónica de 1344, which narrate the legendary origins of the Jewish, Greek and Roman

counterparts (CIPM, Corpus informatizado do Portugues medieval; or: TMILG, Tesouro Medieval Informatizado da Lingua Galega) do not offer a comparable quantity of sources yet. Even without producing an exhaustive ontology, this key-word research permits insights into the very rich variation of the phenomenon for the chosen time period, even if recurrences show privileged, somehow "topical" configurations of material writing. It is logical that a database research can only be a secondary complement to a deeper understanding of the broader textual structures and logics (only available through close reading of entire text corpora). Moreover, we have to be aware that the quantitative approach is necessarily limited as it is dependent on the completeness and the implicit compilation criteria of the respective databases.

8 Aurell 2012 and Gimeno Blay 2006.

9 For the modelling of epitaphs in Portuguese kings' chronicles, see Lang 2017, 87f. 
civilisations. ${ }^{10}$ In contrast, the chronicles mention normal paper or parchment writing as soon as they reach more recent historical events and Iberian settings. In these later passages, the narrative and even the hero's miracles or dream-visions do not contain any inscriptions, privileging instead images, symbolic colours and pictorial emblems. ${ }^{11}$

The legend of King Rocas in the Estoria de España is a particularly revealing example. ${ }^{12}$ An interesting passage (ch. 11) concerning the value of material inscriptions is inserted into the mythical prehistory of Southern Spain. The first settlements like Cádiz, Osuna, Granada and Toledo were founded by Hercules, the Greek King Pyrrhus, and a certain oriental King Rocas, who descended from paradise. Leaving Eden in search of universal wisdom (los saberes), he finds a marvellous place somewhere in a land "between Orient and North", where 70 rich pillars made of marble and brass present the exhaustive writings of "all knowledge and the nature and function of things" (todos los saberes e las naturas de las cosas e cuemo sauien dobrar). It is symptomatic that the mythical founder then acts like the scribes working for Alfonso: Rocas translates the texts into a book, transforming the mythical, locostatic materiality into a mobile and human-made book (fizo [...] un libro que traye consigo). ${ }^{13}$ This helps him to re-activate a hidden (divine?) knowledge which had collapsed with the toppled pillars (pilares [...] yazien en tierra), and make practical use of the prophetical revelations contained therein. Rocas then travels on and becomes an epigrapher himself:

fasta que llego a Troya antes que fuess destroyda la primera uez. [...] e uino por aquel logar o fue depues poblada Roma, y escriuio en un marmol quatro letras de la una parte que dizien Roma; $y$ estas fallo y depues Romulo quando la poblo, e plogol mucho porque acordauan con el so nombre, e pusol nombre Roma. (13)

He even came to Troy before it was destroyed for the first time [...], and he came to the place whereafter Rome had to be built, and there he wrote into a marble four letters saying "Roma". And those letters found afterwards Romulus when he settled the town, and he was very pleased that the letters correponded to his proper name and named it Roma. ${ }^{14}$

10 The recurrence of narrated inscriptions transported in Iberian translations of classical antique texts (for example Juan Fernández de Heredia's Traduccción de Vidas paralelas de Plutarco, c. 1380) shows that the presence of text-bearing architectonic elements could be considered, in the fourteenth century, a cultural aspect of the remote antique world and a result of cultural import.

11 See the Cantar de Mio Cid, and the scene of Afonso Henriques's battle at Ourique in Crónica de 1344. For a purely iconic, alternative writing in the form of the hero's wounds, Barros Dias 2005. Here, the influence of mystical inscription is obvious, see chapter 4 of the present article.

12 See ch. XI De cuemo poblo Pirus a Ossuna et a Granada et del rey Rocas up to ch. XIII (12f.). For this concrete episode, see Riquer 2017; more generally, Fernández-Ordóñez (ed.) 2000.

13 The Alfonsine governance is famous for its attempt to enlarge and renew the bibliographic tradition, translating and transcribing a large corpus of occidental and oriental texts. The same can be said about the Catalan monarch Pere III el Cerimoniós, see Gimeno Blay 2006.

14 All translations are mine. 
In a subtle way, the chronology of the well-known historical facts (the destruction of Troy, the foundation of Rome) is inverted here, placing the founding father Rocas before all others; Romulus simply follows King Rocas's lead when he finds prophetical inscriptions already at the site where he will found Rome (escriuio en un marmol quatro letras de la una parte que dizien Roma; y estas fallo y depues Romulo quando la poblo). Thus, history is perceived in an alternative way, relativizing the common foundational fictions from another epistemic viewpoint. Through the chronological precedence of the material inscriptions, the naming and settlement of the Spanish towns recounted before and after the Rocas episode also appear supernaturally ordained, stemming from a source outside of the flow of human history.

The association of architectural inscriptions with a remote, authoritative past may account for the appeal such phenomena held for narrative accounts of fantastical otherworlds, as we will also find later on in chivalric literature. Two further examples illustrate this otherness generated by narrated inscriptions, this time representing cultural rather than historical alterity. Both texts are translations from other cultural contexts that afterwards become productive sources for the Iberian imaginary. The first example concerns the influence of Arabian textuality in the Iberian Peninsula during the Middle Ages. The presence of inscriptions within story-worlds could be seen as a reflection of Iberian cultural realities since calligraphic writing was an omnipresent visual phenomenon in Muslim urban spaces. However, I would argue that Arabian philosophy and poetics have a more profound influence, introducing not only new ideas and concepts, but intervening on stylistic or discursive levels. ${ }^{15}$

Calila e Dimna (1251) features a fictional inscription that is transformed into doctrinal truth. ${ }^{16}$ This Castilian version of an Arabian narrative manual of wise behaviour and statecraft entitled ك-ليله وَ دِمنه (Kalila wa-Dimna), itself translated from Sanskrit in the seventh century, was introduced in Castile at the time of King Alfonso X, called el Sabio (1221-1284), a time when Christian, Jewish and Muslim religion and culture coexisted in the Castilian kingdom. Alfonso's encouragement of scholarship and translation in particular introduced many Arabic (and thereby also Greco-Roman) texts to Europe. In chapter XIV the conversing protagonists, a King and a Philosopher, discuss a town gate bearing an inscription. The Philosopher relates:

15 A prominent example of an architectonic inscription program is the Granadian Alhambra, see Puerta Vílchez/Núñez 2011.

16 Although the original Castilian text dates from 1251, the two manuscripts in Biblioteca del Real Monasterio de San Lorenzo del Escorial (signatures h-III-9 and x-III-4) are from the fifteenth century. Döhla, who juxtaposes in his critical edition the two manuscripts as A and B, opines "que el ms. A data de principios del s. XV, y el ms. B [...] de 1467” (Döhla 2009, 67). 


\begin{abstract}
"Et ninguno non puede por arte nin por seso desuiar lo que dios le judgo e prometio de antes. Et esto paresçe en el enxemplo del rrey que fizo escriuir sobre la puerta de su çibdat que dezian Matrofil, que el buen entendimiento e la valor e la femençia e la arte en este mundo todas son en poder de la ventura." (441)
\end{abstract}

"And nobody can by ruse or by ingenuity alter the course of what God has judged and provided for him beforehand. And this appears in the example of the King who had written on the gate of his town, named Matrofil, that good understanding and value and strength and art in his world all are in the hands of fortune."

A long exemplum follows explicating the inscription, describing a prince who wanders as a vagrant until one day, as he sits incognito under the city gate of a foreign town, he observes a coronation ceremony and is himself finally recognised as the crowned prince's long lost brother, thereby recuperating his royal honour and wealth. The narrative concludes by emphasizing that the vagrant-king writes down the moral lesson of the tale on the city gate (fizo escriuir sobre la puerta de su çibdat), not only marking the very spot where the crucial encounter took place but also turning the gate into a material document for the very message of the narration: that everything depends on fortune (que el buen entendimiento e la valor e la femençia e la arte en este mundo todas son en poder de la ventura). The gate itself, as setting and source of the narration, links the fictional scene with the "truth" of a stable wise saying outside of the text. The inscription remains fixed on the gate to be referred to in the frame narrative of the King in conversation with the Philosopher, and remains fixed in the text of Calila e Dimna for the use of every (aristocratic) reader. The prince himself

mando escreuir a la puerta de la çibdat estas palabras: "Laz[erio] de vn omne que fara por sus manos en vn dia, puede [ga]nar a el e a tres conpañeros de comer e de beuer. Et compl[imiento] en el omne de beldat e de buen enseñamiento e grant l[inaje] faze le ganar amor de los omnes e faze le perder soledat, [maguer] sea estraño e fuera de su tierra, et faze le ganar en vn [dia çient] maravedis. [...] Et todas las cosas son por el juyzio de Dios et por ventura asy, ca non ha cosa de quantas Dios crio que se pueda mudar vn paso nin cuydar fazer alguna cosa sy non por el mandado de Dios et por lo que ha prometido e judgado. Et todas las cosas son en Su poder, e El las mantiene et El se torna, que ninguno non sabe commo las ordena nin commo las confirma."(452f.)

ordered that these words be written on the town gate: "the hard manual work of a man in one day can give him and three other people to eat and to drink. To accomplish with beauty and good education and nobility makes him gain the love of others and lose solitude, even if he is far away from home, and let him earn in one day 100 Maravedis. [...] And everything is like this, for the judgment of God and Fortune, because there are no things in the divine creation that could move a step or try to do something if it is not for the order of God and for His promise and judgment. And everything is in His power, and He keeps and changes things, while nobody knows how He orders and confirms them." 
Obviously, the very lengthy "inscription" is not only fictive but also allegorical, as the text is not generally concerned with narrative plausibility or verisimilitude. The inscription, however, serves-like a "reality effect" in the narration-as a marker of the static conceptual base underlying the pragmatics of the text. This technique of fixing doctrinal or instructive messages in space enters, perhaps through Arabic textual influence, into Christian theological tractate literature, as we will also see with Ramon Llull.

A second example for the modelling of otherness through inscription concerns a "colonial” ambiance in medieval Iberia. In Fernández de Heredia's (Catalano-)Aragonese version of the Libro de Marco Polo (1396) material writing is part of the description of marvellous alien cultures. ${ }^{17}$ While Marco Polo's travel narrative is obviously not an indigenous Iberian text, it is of particular significance for Iberian literature because Marco Polo's narration of his travels in China presents a model for the depiction of marvellous settings that we later find in some accounts of the colonial Spanish empire from the sixteenth century onwards, such as Alonso de Ercilla's La Araucana (1569-1589). ${ }^{18}$ In the context of the travel narrative's pre-colonial "exoticism", the Far Eastern world of the Gran Chan is as full of text-bearing architecture as the classical Roman and mythological spaces. The grant palaçio del senyor, for example, exhibits a stunning golden opulence, with inscribed furniture. The text describes several tables made of gold and engraved with the pictures of a lion and an elephant, and then insists on the material value of those objects before presenting the inscription they all share:

Por la fuerça del grant dios et de la gracia que ha dada al nuestro imperio, el nombre de nuestro buen can sea bendicho, et todos aquellos que no lo obedeceran sean destruydos et muertos. (21)

For the power of God and the grace He has given to our empire, the name of our good Khan is blessed, and all those who do not obey will be destroyed and killed.

In Marco Polo's setting, material opulence (gold or silver) goes along with the fascination of alterity suggested by the exotic lion and elephant, but also combines with the vocabulary of imperialism: economic value, military conquest and a theological justification based on divine and historical providence. ${ }^{19}$ Interestingly, we will find similar narrations of luxurious text-bearing furniture again in "imported" Arthurian narratives, but also in doctrinal texts, such as those of the Majorcan philosopher Ramon Llull.

17 Biblioteca del Monasterio de El Escorial, Ms Z-I-2. I follow the critical edition of John J. Nitti 1980.

18 See my article on fetishism in the colonial space and its relation to material writing, "Materialización y metapoética desde las novelas caballerescas a la épica colonial" forthcoming in RILCE.

19 For a classical approach on Iberian Imperialism and textual logic, see Quint 1993. 


\section{Ramon Llull: Doctrinal Landscapes and Tangible Writing}

Material writing which becomes visible and tangible within the narrated world is central to Ramon Llull's didactic dialogues. His texts, written c. 1270-1305 in both Latin and Catalan (and some in Arabic), develop a whole "combinatorial" system of moral philosophy adapted to Christian thinking. This system, developed in his texts Art Abreujada d'Atrobar Veritat, Ars generalis ultima, Lògica nova or Arbre de ciència, is accompanied by diagrams that translate allegorical concepts into visible patterns. He uses, for example, a tree as an organic subdivision system, or a ladder leading to heaven to illustrate an argument's logical sequentiality and teleological orientation. However, this visuality is not only represented in the manuscript illuminations, but also inserted into the text itself. In his Llibre del gentil e dels tres savis (c. 1275), Llull fictionalises his doctrinal and philosophical material by creating a minimalist narrative setting for his dialogues. ${ }^{20}$

Much like Boccaccio's Decamerone, Llull's moral dialogues are situated in a locus amoenus which in Llull's text also becomes a material surface on which the essence of the philosophical account is written. Three wise men and a pagan wander through a beautiful landscape, where they encounter five blooming trees and meet the Lady Understanding, whom they ask

que.ls dixés la natura de les proprietats dels V arbres, ni que significaven les letres qui eren escrites en cascunes de les fflors. (9)

to explain the nature and properties of the five trees, and the signification of the letters written on each of the flowers.

In the locus amoenus, the pagan (el gentil) and three monotheistic wise men (representing Judaism, Islam and Christianity) discuss the theological value of virtues (seven divine and seven created virtues) and mortal sins. In each of the trees' flowers one substantive is inscribed (bonea, granea, eternitat, poder, saviea, amor, perfecció, fe, esperança, caritat, etc.). The characters carry on their debate by picking one flower after the other from the trees. The landscape with the tree figures as a narrative realisation of five schematic illustrations in the beginning of the text (al comensament d'aquest llibre) combining the virtues and sins. ${ }^{21}$ The logic of the argument thus also follows the schematic sequentiality of these "combinatorics". With the self-referential comment referring to the illustration, the book doubles its expressive possibilities

20 See the "Pròleg" in Llull 2015, 9-14. Concerning the figure of the Arbor exemplificalis from a literary/aesthetic point of view, see Hauf 2002. For the literary modelling in Ramon Llull more generally, Friedlein 2004 (for Llibre del Gentil, especially 2004, 59-98).

21 See the critical introduction 2015, lv-lix. 
in pictorial and linear narrative argumentation. By creating these parallel modes of mediation, Llull actually "mechanizes" the narrativization of theology. ${ }^{22}$ The inscriptions are not immediately legible, however. As in Dante's Commedia, the protagonists need the guidance of a wise allegorical figure, here dona Entallegencia. The reader identifies with the learning pagan and thereby discovers the points of doctrine together with the fictional characters. In addition to the great mnemonic potential and plasticity of visualization, the text-bearing flowers also present an aesthetic or even synaesthetic dimension: it is not only possible to read, but also to see and smell them (veer e odorar les fflors).

In his Blanquerna novel (1282) Llull goes even further by adding a narrative framework to his discussion of doctrine and materializing his apologetical writing within this imaginary world..$^{23}$ The vital learning process of the young Blanquerna, wandering through the deserted landscape, becoming a monk, bishop and, ultimately, a hermit entirely dedicated to contemplation, is actually comparable to the Arthurian hero's parcours and a chivalric sequence of literary spaces. Blanquerna encounters an allegorical building with a long inscription on the entrance portal spelling out the Ten Commandments in golden and silver letters. As they are disdained in the world, the inscription goes on to explain, the Commandments have withdrawn to this hall to lament. The engraving on the portal does not fail to affect Blanquerna:

Molt fortment fo meravellat Blanquerna con hac llestes les paraules qui eren escrites sobre el portal; e tocà a la porta e volc entrar en lo palau per veer los deu Manaments, (107f.)

Blanquerna was very awed when he had read those words written on the portal; and he touched the door and wanted to enter in the palace to see the Ten Commandments,

which he finds inside personified as seated statues each holding a book.

In this passage, the wording of the Ten Commandments engraved in stone appears as an irrevocable and inalterable truth that predates human understanding. It is obvious that the marvellous palace is not built by human beings. Its inhabitants, the personified text-monuments, are both physically tangible and audible characters; they speak directly to Blanquerna and incarnate a written text to which they give voice. The narration duplicates the literary mediation between architectonic inscriptions and the personified voices, creating a total encounter between the protagonist and the textually grounded doctrinal level. Furthermore, the levels and modes of textual mediation are multiplied between a) the gate inscription, b) the inner walls bearing inscriptions of the human sinners, and c) the personifications holding books that

22 For a programmatic "transmutació de la ciència en literature" (Pring-Mill 1991, 307), also see the newer article collection on Llull's Arbor Scientiae (Domínguez Reboiras/Villalba Varneda/Walter (eds.) 2002). For mechanics and “ars combinatoria”, see also Vega Esquerra 2016.

23 On this paragraph and the problematic of textual monuments within the fictional world, see my article Béreiziat-Lang 2018b. On Blanquerna as apologia see Friedlein 2004. 
register every sinner. Gumbrecht describes such a narrative strategy as "presentification". ${ }^{24}$ Prior to a deeper hermeneutic and rational understanding of the writing, the protagonist finds himself confronted with "text" as a lived experience that operates on all levels of sensory perception. In this sense, Blanquerna's characteristic wonderment (molt fortment fo mervellat Blanquerna con hac llestes les paraules) also recalls the epic heroes of the Arthurian tradition, in which writing as a transcendental phenomenon forms part of the enchanted world of aventures.

Doctrine is materialised in Llull's texts in a marvellous, alien and supernatural fictional setting which merges with the traditional topoi of locus amoenus and eremus. The inscription on the portal evokes the text-bearing pillars in Estoria de España and the gate in Calila e Dimna and likewise materialises doctrinal knowledge in the fictional world. This knowledge aligns the narration with the moral system of the "real" world. Given the place of Llull's works as exemplary of the intellectual engagements catalysed by the so-called convivencia of medieval Iberian Muslim, Jewish and Christian communities, the similarity between Blanquerna and Calila e Dimna suggests that ties between these three literary traditions also included fictional conceptualizations of material writing.

This tendency to materialise abstract doctrinal knowledge within the fictional world is reinforced in the fifteenth century with the emergence of Petrarchism on the Iberian Peninsula. Doctrinal narrations often combine a Llullian setting and dialogue form with Petrarchan topics and increase the presence of allegory and emblematic figures. ${ }^{25}$ These texts feature the rudimentary narrative structure of a quest for knowledge that includes inscriptions. Alfonso de la Torre's Visión deleytable from 1440 demonstrates that such a narrative structure also works well with mystic ascension. ${ }^{26}$ This text, in the form of an allegorical dream, illustrates the journey of Entendimiento, personified Understanding, to the "high mountain" of wisdom, confronting successive visions of allegorical spaces and personifications (Verdat, Razón, Fortaleza etc.) along the way. As in Llull's texts, inscriptions appear both in the stylised landscape setting and as attributes on the bodies of the personifications. In the description of the personifications, material writing combines with the omnipresent symbol of literate culture, a "book":

24 See Gumbrecht 2004.

25 Visión Deleytable has been shown to be influenced by the Jewish philosopher Maimonides (twelfth century, Córdoba), whose writings reflect the Jewish and Arabian philosophies of the time, just as Llull's own texts also do (cf. Girón Negrón 2000).

26 For a broader Iberian perspective on this phenomenon, see my analysis of the Portuguese Boosco deleitoso, in my article Béreiziat-Lang 2018b. 
[la donzella] en la siniestra tenía un libro çerrado, e en somo de las vestiduras tenía unas letras griegas e latynas en que dezía "Ornatus et persuasio" (124)

In her left hand the young lady holds a closed book, and on her clothes she had some Greek and Latin letters saying "Ornatus et persuasio" 27

The Visión deleytable combines graphic, auditive and pictorial elements. Text-bearing artefacts such as clothing, walls and emblematic accessories halt the narrative movement and create visual, pictorial moments in the texts. From an epistemological point of view, this multimedia relation between writing and image, or between visualization and oral reading, is also informed by pre-modern theories of vision and perception. According to these theories, the storing and re-evocation of inner species provide a mnemotechnical structure for the organization of understanding and memory. ${ }^{28}$ Like characteristic physical attributes, inscriptions can therefore aid the mental processing of abstract, doctrinal knowledge. While the theme of the encounter is laid out in the static allegorical inscriptions, an oral dialogue further develops its significance. Additionally, the protagonist's understanding is supported by a secondary visual dimension: the content of the dialogue is simultaneously depicted on the walls. Thus, the preceding "truth" of the spoken doctrine is cemented beforehand within the fictional world:

E estas cosas por orden declaradas, la donzella, fecha fin a su fabla, estovo en un agradable sylençio. E entonçes el Entendimiento paró mientes en las paredes de la casa e vido todas las cosas susodichas e pintadas por orden. (114)

And as those things were fairly declared, and the young lady stopped talking she was in a pleasant silence. And then, Understanding fixed his attention on the walls of the house and saw all the things that have been told above painted in the right order.

Fixing the protagonist's gaze on the pictures (paró mientes), the narration halts for a reflective moment of comprehension-a comprehension which is not only hermeneutic and analytic, but pervades all senses. Between mystical ascension and a hero's learning parcours, those doctrinal texts evoke two different textual traditions, showing the adaptive flexibility and fusion of diverse discursive practices. As we will see, textual patterns of different literary genres such as mystical treatise, religious prose and chivalric novels can be combined for a new textual pragmatics.

27 We find parallel examples in Visión deleytable 1991, 107 (text-bearing tablets) or 116 (text-bearing flowers), among others. It is revealing that those inscriptions are mostly hold in Latin, while the running text is in Castilian.

28 See Carruthers 2008, 60-65; Hahn 2000; Folger 2003 and 2016, 233. Yates 1999, 173-198 discusses the art of memory in Llull in particular. 


\section{From Arthurian Chivalry to Mysticism: Narrative Logic and Wonder}

The "Arthurian colour" 29 of these doctrinal and philosophical treatise show how flexibly Iberian literatures retextualised literary inspirations. Since scholars can only examine Arthurian texts in Iberian vernaculars by way of their surviving early modern transcriptions, the impact of the initial medieval Iberian reception of the Matter of Britain is difficult to estimate. ${ }^{30}$ The first dating of a closer Vulgata translation being 1313, in a sixteenth-century manuscript of the Portuguese Josep Abaramatia (an adaption of Estoire de Saint Graal), the earlier diffusion of the Arthurian texts seems to have been underestimated..$^{31}$ Indeed, several texts of the fourteenth century, without being proper translations, show Arthurian motifs, ${ }^{32}$ but do not pay attention to narrated inscriptions. The "Arthurian" texts presenting numerous and creative new re-modellings of this phenomenon only appear in manuscripts from the late fifteenth century..$^{33}$ Proper translational adaptions concerning the Post-Vulgate-cycle are, for example, El baladro del sabio Merlín con sus profecías (first printed in Burgos in 1498), ${ }^{34}$ the manuscript MS 1877 of Biblioteca Universitaria de Salamanca, compiled in 1467-1470 by Petrus Ortiz and containing the Libro de Josep Abarimatía, Estoria de Merlín and Lançarote (the latter corresponding to Mort Artu), or La demanda del Sancto Grial (c. 1470)..$^{35}$ In this latter text, as in another version of Lançarote del Lago

29 Malkiel 1959, 413.

30 See especially Malkiel 1959 and for a newer approach, Hook (ed.) 2015 and Sharrer 1994, 175-190. For the diffusion of the "Matière de Bretagne" on the Iberian Peninsula, Mérida Jiménez 2013, 13-34. 31 Sharrer 1994, 175. Malkiel $(1959,406)$ gives 1170 as a first date, in relation to the Catalan troubadour Guiraut de Cabrera, who mentions the "literary fashion" of Arthurian themes because of his familiarity with the Provençal scope.

32 The oldest Castilian chivalric book Libro del Caballero Zifar (c.1300), for example, shows motifs from Yvain. Likewise, La Faula (c. 1370) written by the Majorcan Guillem Torroella is a creative adaption of different Arthurian motifs; and La gran conquista de Ultramar (c. 1295) picks up scenes from the Chanson du Chevalier au Cygne and makes allusions to the Round Table.

33 See Mérida Jiménez 2013.

34 This adaption (ed. Bohigas, 1957-1962) also contains traces of Hélie de Boron's Conte de Brait. For the "re-writing" of the French Suite du Merlin in this Castilian text, see the exhaustive comparative study of Rosalba Lendo. She notes several important modifications like "suppression ou modification de certains épisodes, moralisation de divers passages, réduction ou rationalisation des éléments merveilleux, transformation de quelques personnages. Ces modifications témoignent du caractère mouvant du roman arthurien" (Lendo 2001, 416). For the issue of a Catholic moralization of the French subtext, see also Mérida Jiménez 2013, 45-70. A second Castilian print version is El baladro del sabio Merlín. Primera parte de la demanda del sancto Grial (Sevilla 1535); first Galaico-Portuguese adaptions seem to be older (cf. Lendo 2001, 428).

35 Bogdanow (1991) presents an attempt to reconstitute the Post-Vulgate cycle from French, Spanish and Portuguese texts. 
(anonymous, 1414), ${ }^{36}$ written instructions to the hero in an enchanted sylvan landscape (floresta) frame the parcours of his adventures:

$[Y]$ ante la hermita estava en el cimenterio vna Cruz en un padrón de marmól. Y quando Don Lançarote vido la cruz, cató sobre el padrón y vio letras vermejas que dezian: "Oyes, tú, cavallero andante que buscas las aventuras, si tú no quieres tu muerte o tu desonra, guarda que no entres en esta floresta, ca te non podras ende partir sin una d'estas dos cosas." (339)

[And] in front of the hermitage on the cemetery there was a cross in a marble column. And when Don Lançarote saw this cross and looked on the column and saw red letters that said: "Listen, errant knight in search of adventures, if you do not want death or dishonour, keep from entering this forest, because you won't be able to come out again without suffering one of the two."

The writing addresses the hero directly (oyes tu Cauallero andante). The fictional world itself is given an intradiegetic voice. Yet, the protagonist does not answer or react-he makes the narration pause for a meta-commentary. The hero's examination of the inscription, which is also the script of his fatal parcours, directs the reader's eye to the inherent logic of the discourse. The prophetic writings, existing solely to be found by the hero and suggesting imminent danger with red letters, create suspense and guarantee narrative coherence at the same time. Just as with the 70 pillars in the legend of King Rocas, the protagonist is confronted with material writing which arises from the inner logics of the world (and the text) and predates human understanding and activity. The magic writing here functions as a (purely textual) meta-commentary on the meaningfulness of the narration and of textuality in general.

A more flexible, genuine Iberian reception and adaptation of Arthurian themes became very popular up until to the fifteenth century. Of special interest is the Amadís-cycle, created during the fourteenth century but surviving in Garci Rodríguez de Montalvo's version from 1496, and printed 1508 in Zaragoza. Since most of the Amadis-cycle dates from the sixteenth century, ${ }^{37}$ I will concentrate on Montalvo's first book, Amadis de Gaula, written before 1500. Amadís's parcours is also replete with magic inscriptions that inscribe his success and heroism into the very landscape. In one of the first scenes of the novel, Amadis arrives on a hidden island with his beloved Oriana and his chivalric friends, where a enchanted and opulent architectural complex erected by a former king and his beloved tests who is the new leal amador and most worthy knight. The names of the most perfect couple magically appear on

36 BNE Madrid, ms. 1196. For the connections of the Castilian text with the prose Lancelot and the cycle Post-Vulgate, see Correia 2013.

37 Sergas de Esplandián, Palmerín de Olivia, Floriseo, Clarián de Landanís, Amadís de Grecia, Florambel de Lucea, etc. are all full of text-bearing artefacts, illustrating the great popularity of the chivalric ambiance in the sixteenth century, a time marked by nostalgia for the lost and fantastic chivalric world. 
the walls of a gate when the "ones" march through it-launching at the same time an interplay of synaesthetic automata:

"Pero si tal caballero, o dueña, o donzella aquí viniere que sean dinos de acabar esta Aventura por la gran lealtad suya [...] entrarán sin nengún entrevallo, y la ymagen hará tan dulce son que muy sabroso sea de oýr a los que lo vieren, y estos verán las nuestras ymágenes, y sus nobres scriptos en el jaspe, que no sepan quién los escrive." Y tomándola por la mano a su amiga, la fizo entrar debaxo del arco, y la ymagen fizo el dulce son, y mostróles las ymágenes y sus nombres dellos en el jaspe scriptos. (I. 366)

\begin{abstract}
"But when such a knight or lady or young lady, worthy to finish this adventure by their great faithfulness, come here, [...] they will enter without delay, and the image will emit such a sweet sound that it will be a pleasure for them who will see it, and those will also see our pictures, and their names written in the jasper without knowing who writes them.” And taking his beloved by the hand, he made her enter under the arch, and the image emitted the sweet sound and showed them the pictures and their names written in the jasper.
\end{abstract}

The magic writing was programmed by a former hero and appears by itself. Thus, the value of the new hero is already inscribed in the fictional world and has to be accepted as an a priori truth. His proper name, engraved in jasper, naturally corresponds to his "realistic" (read: recognizable) visual representation. The hero is validated by the coincidence of both the name and the picture, and by an acoustic sign. Via the stone inscription, the fictional setting itself confirms the truthfulness of the plot.

A narrative programme may also be inscribed into the very flesh of the hero, as the Amadis-cycle illustrates in the tale of Amadis's son Esplandián. The knowledge of the hero's genealogy and condition are closely linked in the narrative to the "reading" of his bodily marks. After Oriana gives birth to Esplandián a troubling discovery is made on the newborn's body. Undressing him,

vieron que tenía debaxo de la teta derecha unas letras blancas como la nieve, y sola teta isquierda siete letras tan coloradas como brasas bivas (II. 654)

they saw that he had under his right breast some snow-white letters, and under the left breast seven letters deeply red like living fire.

The magic writing on his breast is bicoloured and illegible: the red and white letters are in incomprehensible Latin and Greek (de latín muy escuro y [...] en lenguaje griego muy cerrado). Like the fictional characters, the reader is confronted with a "dark" (escuro) enigma. Over the course of Esplandián's numerous adventures the letters of his inscribed destiny become legible as his name and the name of his beloved, the only one capable of making the letters speak. As in Llull's schematic tree-writings, the meta-writing on the body of the hero reveals the narrative development of the whole plot and thus appears as a shortened, emblematic micro-narrative.

The inscribed messianic child of romance recalls marvellous scenes of "holy writing” found in hagiographical and mystical texts. A number of holy men likewise have 
their sanctity confirmed by inscriptions on their breasts, such as Lazaro in the Cancionero de Juan Fernández de Íxar (c.1470), who is found with letters inscribed into his heart

que dezian asy: con el mio Ihesu Christo. E asy los medicos entendieron la condiçion de aqueste onbre, e dixeron que era muerto de soberana alegria. (LXXVIII. 697f.)

saying: "With my Jesus Christ”. And so the doctors understood the condition of this man and said that he had died from sovereign joy.

The ignorant physicians, limited to a profane, experimental approach, are confronted by this miraculous inscription, prior to human understanding. Whereas Esplandián's breast-inscription prefigures his heroic path, the destiny of the saint's life is already written in his heart. In the well-known legend of Saint Ignatius, the heart-inscription is multiplied. As the collection of Sermones de la Real Colegiata de San Isidoro de León recounts, Ignatius,

en la tribulaçión suya andando sobr'el fuego, sienpre dezía el nonbre de Ihesú si el fuego non le enpesçió. Preguntáronle por qué dezía aquel nonbre tantas vezes e rrespondió que assí estava sellado en su coraçón, que lo non podía partir de su boca. E quando muere el bueno de Inaçio, abriéronle el coraçón en muchas partes e en cada parte le fallan el nonbre de Ihesús escripto de letras de oro. (236)

who in his tribulation walked on fire, was always spelling out Jesus' name when fire didn't hurt him. They asked him why he repeated this name so many times and he answered that the name was so much sealed within his heart that he couldn't quit it from his mouth. And when this good Ignacio died, they opened up his heart in many places and everywhere they found Jesus' name written in golden letters.

Though Ignatius's invocation of the name of Jesus Christ seems to allow him to walk on fire without being burned, the sacred name nevertheless leaves a miraculous mark. The physicians examining his corpse find the holy name engraved in golden letters wherever they cut into his heart. In contrast to the example of Lazaro, the writing here is not affixed to any particular place; rather, it is mobile and ephemeral, and appears only to the eyes of the incredulous public.

In accounts of saints like Ignatius, religious persuasive power and narrative surprise come together in a conception of the marvellous that needs tangible, material stories to make concrete a doctrinal "truth". These supposedly documentary tales of the saints' bodies reverberate in the mystical texts of the Iberian sixteenth century. Nevertheless, in the poetical attempts to articulate the marks of holiness, both the corporal dimension and the aspect of writing tend to be re-allegorised, becoming merely textual references. According to her own poetry, Teresa de Ávila's heart bore an inscription engraved by God himself. Functioning as a refrain, this inscription becomes the structural framework of the poem: 


\author{
Vivo sin vivir en mí \\ y tan alta vida espero \\ que muero porque no muero. \\ Vivo ya fuera de mí, \\ después que muero de amor, \\ porque vivo en el Señor, \\ que me quiso para sí; \\ cuando el corazón le di \\ puso en mí este letrero: \\ "Que muero porque no muero". \\ (955f.)
}

\author{
I live without living in myself, \\ and I hope to have so high a life, \\ that I die because I do not die. \\ I live now outside of myself, \\ after I'm dying of love \\ because I live in the Lord \\ who claimed me for himself; \\ when I gave him my heart \\ He put on it this label, \\ "That I die because I do not die".
}

The message on the tablet in the nun's heart indicates the allusive wordplay, typical of seventeenth-century Spanish Conceptism, which underlies the entire poem: the paradoxal impossibility of living before death (Que muero porque no muero). The inscription marks the body as the very arena of this existential combat. At the same time, God's intimate heart-writing also appears as the origin and motor of the poem's structural logic. The link between hagiography, chivalric models and even mystical texts (such as though Teresa de Avila, Juan de la Cruz or Luis de León), which all fashion an amalgamation of body and text, is suggestive and requires more detailed study. ${ }^{38}$ As a special form of meta-textuality which works as a visualisation of the textual structure and as mise en abyme of the inherent logic of a hero's development, narrated inscriptions also reveal the permeability of genres. In Llull's doctrinal landscapes, the magic world of the knights and the transcendent experiences of the mystic, "presentification" via material writing allows the reader to perceive a hidden "truth" uncovered with the help of text.

\section{Material Scripture and Poetics: Visual Communication in the Courtly Romance}

Gradually, narrated inscriptions become independent from the narrative plot as soon as they become a stage for poetic expression. In the Arthurian (post-Vulgate) text $E l$ baladro del sabio Merlín, we find a first example for this poetization of material scripture. The 1498 print version by Juan de Burgos is an interesting case study for the development of chivalric literatures on the Iberian Peninsula. As H.L. Sharrer first pointed out, a comparison of the French Suite du Roman de Merlin (Ms Huth) and the Iberian versions reveals important changes. ${ }^{39}$ The episode of the love affair of King

38 Although it is a topos in research that Teresa de Ávila read during her youth the Amadís novels and other chivalric texts, see Carrión 1994, 36.

39 See Sharrer 1984. 
Assen's son Anasteu is significantly modified in that the unfortunate couple is killed off. $^{40}$ But of the two Castilian print versions (1498 Burgos and 1535 Sevilla) only the 1498 version introduces an epitaph on the grave of the young lovers. The infante, tragically forced by his father to kill his beloved, mortally wounds himself, and orders his servants to persuade the king to construct a funeral monument for them. The next day, his father finds his dead son and hears his last will, in particular the funerary inscription to be put on their grave:

\footnotetext{
"Bien como cisne que llora su muerte quando consiste, que la dize e la memora con aquel gemido triste, asi mi mal lloraré con un sospiro profundo la vida que dexaré de aqueste cativo mundo. Lloraré mis tristes males, [...]; lloraré la fin venida de aquesta que muerta veo, pues que la fin de su vida dio morir a mi deseo." (III. 68-70)

"Like the swan weeping his dead when it is a question of telling and memorizing it, with this sad moaning so will I complain my suffering with a profound sigh, the life in this unhappy world that I will leave.

I will cry over my sad sufferings, [...]

I will cry over the end of the person that I see dead because the end of her life gave death to my desire."
}

Curiously, this inscription corresponds exactly to the "Lamentación de Grimalte" made in front of Fiometa's grave in Juan de Flores's Castilian sentimental romance Grimalte e Gradissa (c. 1495). ${ }^{41}$ In this novel, largely inspired by Boccaccio's Fiammetta, the medieval chivalric spirit and a new courtly Renaissance ambiance come together. ${ }^{42}$ Vice versa, the affinity of the 1498 Baladro to the sentimental genre shows the editor Juan de Flores's attempt to link medieval chivalric and courtly Renaissance patterns..$^{43}$ In any case, the narrated inscriptions play an entirely different role in this

40 La Suite du Roman de Merlin (1996, 330). See also Morros 1988, 468-469.

41 See Grimalte y Gradissa (1971, 54). For this comparison, see the Sharrer 1988; Morros 1988, 469; Lendo 2001.

42 On the "chivalric" debt in Juan de Flores's novel, see Waley's introduction in Grimalte y Gradissa (1971, xxiii-xxvii).

43 In Grimalte y Gradissa, the tomb, described just after Grimalte’s “Lamentation”, is richly adorned with poetic inscription. On one side, on the banner attached to the tomb wall is painted a boat without oars bearing this poetic inscription on its canvas: En esta barca de amor / y mar de vana esperança, / es un barquero, Dolor, / que en el aprieto mayor / al más peligro se lança. / Y la árbol, que es la Ventura, / con vela poco segura, / en este piélago tal, / acostándose procura / al cabo de mayor mal. (1971, 55). This poem about the fatal uncertainties of love, on his part, is used again in an epitaph cited in the chivalric adventure Tristán de Leonís, printed in 1501 (cf. Waley 1971, XXV; Morros 1988). This fact 
"sentimental" context into which the Arthurian model is transposed. The inscriptions are no longer the result of a marvellous or divinely inspired landscape where they fulfil an informative function intimately linked to the workings of the narrative and the implicit development of the hero. Instead, the cited grave inscriptions are poetic materializations marginal to the narrative's plot and increasingly independent from it. As a lyric commentary on the plot, they serve to underline a heightened sensibility for artistic invention and allegorical depth.

As we have seen in both Teresa de Ávila's poem and in the Arthurian adaptations, an increasing poetization of the inscriptions turns them into lyrical parentheses and converts the text into a pastiche of prose and poetry fragments. ${ }^{44} \mathrm{~A}$ similar tendency can be observed in the original novelas caballerescas and sentimentales which prefigure further narrative developments in the sixteenth and seventeenth century, the Castilian Golden Age (Siglo de Oro). The flexibility with which lyrical fragments can be inserted into narrative plots suggests that both the chivalric and the sentimental romance become ingenious literary exercises, giving (sometimes ironical) winks to the reader who has to decipher the poetic outcome of the author's intertextual links. From a historical perspective, these poetical insertions into prose narratives and the poetical re-elaboration of well-known lyrical fragments have been linked to the increasing popularity of tournament practices. ${ }^{45}$ The short poems collected during the tournaments held in 1474 in Valladolid by the Catholic Kings and compiled in the fifth part of Hernando de Castillo's Cancionero General (printed in 1511 in Valencia), show the social importance and the great poetic impact of this micro-genre that combines emblematics and poetry, letters, images and (self-)performance. ${ }^{46}$

From the second half of the fifteenth century onwards, this genre of letras $e$ invenciones was successively introduced into fictional texts such as Diego de San Pedro's sentimental romances Arnalte y Lucenda (1491) and Cárcel de Amor (1492) ${ }^{47}$ and into the Old Valencian chivalric romance Tirant lo blanc (1490) by Joanot Martorell. ${ }^{48}$ Much like the bodily writings in the Amadis-cycle, the protagonists carry inscriptions through the fictional world; but now their clothing becomes the preferred text-bearing surface, as a means of courtly self-fashioning. ${ }^{49}$ In contrast to the hero's breast inscriptions which prescribe his core identity, vestimentary fashioning of a character's status is more dynamic and flexible. Furthermore, the artificial, human-made character of the inscriptions is emphasised. The challenge, for both protagonist and reader,

might show, once again, the flexibility of re-textualizing poetical fragments in different generical and semantical contexts.

44 Cf. Haywood 1997.

45 Cf. Haywood 1997; Dreyermond 2002; Macpherson 1998.

46 Cf. Macpherson 1998.

47 Casas Rigall 2008; Folger 2016.

48 Beltrán 2005; Lang 2017, 92-103.

49 Cf. Greenblatt 1980. 
of deciphering the inherent logic of a narrative world transforms here instead into a deliberate play between an ingenious textual invention and the reader's hermeneutic and aesthetic pleasure. Moreover, in the context of this poetical self-fashioning, the inscriptions allow the fictional characters to "write themselves". In the sense of Foucault's écriture de soi, they determine their subjectivity by means of poetical self-expression..$^{50}$

In Tirant lo blanc, the first chivalric narrative with inserted invenciones, a complex interplay of changing text-bearing clothes accompanies the plot and builds a self-sufficient textual field with its own "micro-narrative" potential. ${ }^{51}$ A silent but highly poetical dialogue of letras between the protagonist Tirant and his beloved Carmesina, the princess of Constantinople, is sewn onto their opulent dresses (I. 227). In the midst of his elegantly dressed followers, the hero Tirant stands out due to the ingenious textual adornment decorating his coat and his legs, an interplay of figurative elements in the form of ears made out of pearls and an embroidered inscription (un mot brodat) that reads: "One is worth a thousand, and thousands are not worth the one" (Una val mill e mill no valen una). The homophony between Catalan mill (thousand) and mill (ear) creates a pun linking text and image. Carmesina "answers" silently with another combination of text and image on her clothes. Her dress is covered with depictions of a mysterious plant called amorvall ("love counts") surrounded by inscriptions saying: "but not for me" (Mas no a mi). Thus, she implicitly rejects Tirant's courtship, even as Tirant's "invention" exalts both her and his value with an equally precious decoration.

The entire scene takes place in the presence of the king, who monopolises the spoken word (l'Emperor [...] dix a Tirant) while the two lovers only interact through their material wordplays-without any intradiegetical comment on their legibility or the reactions of others. Here Tirant and Carmesina figure as static, emblematic text-monuments; ceding their own voices to the King, they convert themselves into texts. ${ }^{52}$ Even as the scene depicts the characters' coded communications, the narrative focuses its attention on the reader's ability to imaginatively reconstruct a complex pictorial scene and to appreciate its poetic inventiveness. ${ }^{53}$ Only through the narrator's commentary on the name of the pictured plants does the wordplay succeed. And only the reader can realise the relationship between the novel's narrative as a whole and the situational, emblematically frozen state of mind of the protagonists in this scene. As a poetic, purely textual meta-commentary on the narrative structure

50 Cf. Foucault 1994.

51 For the invenciones in Tirant, see Beltrán 2005, 138. See the question of micro-relatos in: Casas Rigall 2008, 50; Dreyermond 2002.

52 For the tendency of de-semantization in the context of a parallel emblematical scenification of "vacuous" communication and the power structure in this text, see also my interpretation in Béreiziat-Lang 2018a.

53 The theatral aspect of Tirant lo blanc has been developed in Beltrán 1999. 
and as an alternative narrative development between the lines, the embroideries also stage the author's ingenuity, creating a kind of poetic tournament with the reader as spectator. ${ }^{54}$

Readers of this survey will no doubt have observed that narrated inscriptions in the Iberian literatures are hardly mimetic representations of inscriptions in the material world. Instead of representing a historical "reality" (i.e. an echo of existing text-bearing architecture or courtly tournament practices) the fictional urban settings and landscapes of Iberian literatures rather use inscriptions to underscore their artificial nature. Although they play with an imaginative potential framed within the episteme of the time, narrated inscriptions function as markers of fictionality, staging purely textual strategies: intertextuality and retextualization shape the mise en scène of these short "texts within the text", which function as metatextual or even metafictional commentaries. The material and visual presence of these metatextual fragments reveal the workings of the entire text. And, as we have seen in late medieval courtly romance (and in contrast to the Arthurian tradition), the inscriptions become increasingly alienated from the plot. The meta-commentary on texuality itself becomes an independent, alternative mode of expression alongside the course of the narrative.

\section{Works Cited}

\section{Primary texts}

Alfonso de la Torre (1991), Visión deleytable, ed. by Jorge García López. Salamanca.

El baladro del sabio Merlín, segun el texto de la edición de Burgos de 1498 (1957-1962), 3 vols., ed. by Pedro Bohigas, Barcelona.

Cancionero de Juan Fernández de Íxar (1956), 2 vols., ed. by José María Azáceta, Madrid. Fernández de Heredia, Juan (1980), Juan Fernández de Heredia's Aragonese version of the Libro de Marco Polo (Monasterio de El Escorial, Ms Z-I-2), ed. by John J. Nitti, Madison. Juan de Flores (1971), Grimalte y Gradissa, ed. by Pamela Waley, London. Lanzarote del Lago (2006), ed. by Antonio Contreras Martín and Harvey L. Sharrer, Alcalá de Henares.

El libro de Calila e Dimna (1251). Nueva edición y estudio de los dos manuscritos castellanos (2009), ed. Hans-Jörg Döhla, Zaragoza.

Llull, Ramon (20153), Llibre del Gentil e dels Tres Savis, ed. by Antoni Bonner, Palma de Mallorca. Llull, Ramon (1987²), Llibre d'Evast e Blanquerna, ed. by Maria Josepa Gallofré, Barcelona. Martorell, Joanot (1983), Tirant lo blanc, 2 vols, ed. by Martí de Riquer, Barcelona.

54 In Pedro Núñez's continuation of the sentimental romance Cárcel de Amor (1492), the situation is very similar. The silent dialogue established between the text-bearing clothes of the beloved Laureola and Leriano might be the paroxysm of an artificialization of the sentimental dialogue, see Folger 2016, $227-231$. 
Primera Crónica General. Estoria de España que mandó componer Alfonso el Sabio y se continuaba bajo Sancho IV en 1289 (1906), vol.1, ed. by Ramón Menéndez Pidal, Madrid.

Rodríguez de Montalvo, Garci (1997), Amadís de Gaula, 2 vols., Madrid.

Los sermones en romance del manuscrito 40 (siglo XV) de la Real Colegiata de San Isidoro de León (2002), ed. by Pedro Cátedra, Salamanca.

La Suite du Roman de Merlin (1996), 2 vols., ed. by Gilles Roussineau, Geneva.

Teresa de Ávila (1954), Obras Completas de Santa Teresa, vol. 2, ed. by Efrén de la Madre de Dios, Madrid.

\section{Database}

Corpus diacrónico del español (CORDE), Real Academia Española, <http://www.rae.es> (last accessed: 24.11 .2017$)$.

\section{Secondary sources}

Aurell, Jaume (2012), Authoring the Past. History, Autobiography and Politics in Medieval Catalonia, Chicago.

Barros Dias, Isabel de (2005), “'In hoc signo ...”, in: Des(a)fiando discursos. Homenagem a Maria Emília Ricardo Marques, Lisboa, 315-326.

Beltrán, Rafael (1999), “Comedy and Performance in Tirant lo Blanc”, in: Arthur Terry (ed.), Tirant lo Blanc. New Approaches, London, 15-28.

Beltrán, Rafael (2005), “La noria con arduces (cimera de Jorge Manrique) y otras doce invenciones poéticas en Tirant lo Blanc", in: Pedro M. Piñero Ramírez (ed.), Dejar hablar a los textos. Homenaje a Francisco Márquez Villanueva, vol.1, Sevilla, 135-154.

Béreiziat-Lang, Stephanie (2018a), "Tirant lo Blanc. Del poder de las palabras al gobierno del signo vacío", in: Christoph Strosetzki (ed.), Aspectos actuales del hispanismo mundial. Literatura Cultura - Lengua, Berlin, 402-413.

Béreiziat-Lang, Stephanie (2018b), "Körper versus Schrift? Mystische Erfahrung als intertextuelle Polyphonie im Boosco deleitoso (1515)", in: Lusorama 107/108, 5-36.

Bogdanow, Fanni (1991), La version post vulgate de la Queste del saint Graal et de la Mort Artu. Troisième partie du Roman du Graal, 3 vols., Paris.

Cano Aguilar, Rafael (1992²), El Español a través de los tiempos, Madrid.

Cano Aguilar, Rafael (2004), Historia de la Lengua Española, Barcelona.

Carrión, María M. (1994), Arquitectura y cuerpo en la figura autorial de Teresa de Jesús, Madrid.

Carruthers, Mary $\left(2008^{2}\right)$, The Book of Memory. A Study of Memory in Medieval Culture [1990], Cambridge.

Casas Rigall, Juan (2008), “El mote y la invención en la estructura narrativa de Cárcel de

Amor", in: Cancionero General 6, 33-61.

Cichon, Peter (2012), “Das Spanische als Romanische Sprache”, in: Joachim Born, Robert Folger, Christopher F. Laferl and Bernhard Pöll (eds.), Handbuch Spanisch. Sprache, Literatur, Kultur, Geschichte in Spanien und Hispanoamerika, Berlin, 3-7.

Correia, Isabel Sofia Calvário (2013), "O ciclo do Pseudo-Boron e o estatuto do Lancelot ibérico", in: Lénia Márcia Mongeli (ed.), De cavaleiros e cavalarias. Por Terras de Europa e Américas, São Paulo, 271-283. 
Dreyermond, Alan (2002), “La micropoética de las invenciones”, in: Juan Casas Rigall and Eva María Díaz Martínez (eds.), Iberia cantat. Estudios sobre poesía hispánica medieval, Santiago de Compostela, 403-424.

Eberenz, Rolf (1991), “Castellano antiguo y español moderno. Reflexiones sobre la periodización en la historia de la lengua", in: Revista de Filología Española LXXI, 79-106.

Fernández-Ordóñez, Inés (ed.) (2000), Alfonso X el Sabio y las Crónicas de España, Valladolid.

Domínguez Reboiras, Fernando/Villalba Varneda, Pere/Walter, Peter (eds.) (2002), Arbor Scientiae. Der Baum des Wissens von Ramon Lull, Turnhout.

Folger, Robert (2003), 'Generaciones y semblanzas'. Memory and Genealogy in Medieval Iberian Historiography, Tübingen.

Folger, Robert (2016), “Die Imagination der Materialität. Das Liebesgefängnis (Cárcel de amor 1492), Metatextualität und soziale Praxis", in: Friedrich-Emanuel Focken and Michael Ott (eds.), Metatexte. Erzählungen von schrifttragenden Artefakten in der alttestamentlichen und mittelalterlichen Literatur (Materiale Textkulturen 15), Berlin, 217-238.

Foucault, Michel (1994), “L'écriture de soi”, in: Dits et écrits, vol. 4, Paris, 415-430.

Friedlein, Roger (2004), Der Dialog bei Ramon Llull. Literarische Gestaltung als apologetische Strategie, Tübingen.

Gimeno Blay, Francisco (2006), Escribir, reinar. La experiencia gráfico-textual de Pedro IV el Ceremonioso, Madrid.

Girón-Negrón, Luis M. (2000), Alfonso de la Torre's Vision deleytable. Philosophical Nationalism and Religious Imagination in Fifteenth-Century Spain, Leiden.

Greenblatt, Stephen (1980), Renaissance Self-Fashioning. From More to Shakespeare, Chicago.

Gumbrecht, Hans Ulrich (2004), Diesseits der Hermeneutik. Über die Produktion von Präsenz, Frankfurt.

Hahn, Cynthia (2000), “Visio Dei. Changes in Medieval Visuality”, in: Robert S. Nelson (ed.), Visuality before and beyond the Renaissance. Seeing as Others Saw, Cambridge, 169-196.

Hauf, Albert G. (2002), "Sobre l'Arbor exemplificalis", in: Fernando Domínguez Reboiras, Pere Villalba Varneda and Peter Walter (eds.), Arbor Scientiae. Der Baum des Wissens von Ramon Lull, Turnhout, 303-342.

Haywood, Louise M. (1997), “Lyric and other Verse Insertions in Sentimental Romances”, in: Joseph J. Gwara and Michael E. Gerli (eds.), Studies on the Spanish Sentimental Romance (1440-1550), London, 191-206.

Hook, David (ed.) (2015), The Arthur of the Iberians. The Arthurian Legends in the Spanish and Portuguese Worlds, Cardiff.

Lang, Stephanie (2017), “Von bezeichneten Körpern und beschrifteten Schuhen. 'Körperschrift' und Narration in iberischen Literaturen des 14. und 15. Jahrhunderts", in: Ludger Lieb, Stephan Müller and Doris Tophinke (eds.), Graffiti. Deutschsprachige Auf- und Inschriften in sprach- und literaturwissenschaftlicher Perspektive, Wien, 77-108.

Lendo, Rosalba (2001), "Du Conte du Brait au Baladro del Sabio Merlín. Mutation et déécriture”, in: Romania 119, 414-439.

Macpherson, Ian (1998), The 'invenciones y letras' of the 'Cancionero general', London.

Malkiel, Maria Rosa Lida de (1959), "Arthurian literature in Spain and Portugal”, in: Roger Sherman Loomis (ed.), Arthurian Literature in the Middle Ages, Oxford, 406-418.

Mérida Jiménez, Rafael M. (2013), Transmisión y difusión de la literatura caballeresca. Doce estudios de recepción hispánica (siglos XIII-XVII), Lleida.

Morros, Bienvenidos (1988), “Los problemas ecdóticos del Baladro del Sabio Merlín”, in: Vicente Beltrán (ed.), Actas del I Congreso de la Asociación Hispánica de Literatura Medieval, Barcelona, 457-471.

Penny, Ralph J. (1991), A History of the Spanish Language, Cambridge. 
Pring-Mill, Robert D. F. (1991), Estudis sobre Ramon Llull (1956-1978), Montserrat.

Puerta Vílchez, José Miguel/Núñez, José Agustín (2011), Reading the Alhambra. A visual Guide to the Alhambra through its Inscriptions, Granada.

Rabella, Joan Anton (2012), “Oralitat i escriptura. La llengua catalana a l'edat mitjana”, in: Juan Pedro Sánchez Méndez (ed.), Oralidad y Escritura en la Edad Media hispánica, Valencia, 53-85.

Quint, David (1993), Epic and Empire. Politics and Generic Form from Virgil to Milton, Princeton, New Jersey.

Riquer, Jeneze (2017), Iberia legendaria (24). La leyenda del rey Rocas, rey de Oriente, in: cervantesvirtual, 〈https://cvc.cervantes.es/el_rinconete/anteriores/septiembre_17/08092017_01.htm〉 (last accessed: 12.11.2017).

Sharrer, Harvey L. (1984), "La fusion de las novelas artúrica y sentimental a fines de la Edad Media", in: El Crotalón. Anuario de Filología Española 1, 147-157.

Sharrer, Harvey L. (1988), “Juan de Burgos. Impresor y refundidor de Libros caballerescos”, in: María Luísa López-Vidriero and Pedro M. Cátedra (eds.), El libro antiguo español. Actas del Primer Coloquio Internacional, Salamanca, 361-369.

Sharrer, Harvey L. (1994), "The Acclimatisation of the Lancelot-Grial-Cycle in Spain and Portugal”, in: William W. Kibler (ed.), The Lancelot-Grail Cycle. Text and Transformations, Austin, 175-190.

Vega Esquerra, Amador (ed.) (2016), La máquina de pensar. Ramon Llull y el 'ars combinatoria', Barcelona.

Videira Lopes, Graça (2005), “Modelo e contra modelo. 0 retrato de Afonso Henriques nos textos medievais", in: Ana Sofia Laranjinha and José Carlos Ribeiro Miranda (eds.), Modelo. Actas do V Colóquio da Secção Portuguesa da Associação Hispânica de Literatura Medieval, Porto, 129-139.

Yates, Frances (1999), “Lullism as an Art of Memory” [1966], in: Selected Works, vol. 3: The Art of Memory, London/New York, 173-198.

White, Hayden (1981), "The Value of Narrativity in the Representation of Reality", in: William J. T. Mitchell (ed.), On Narrative, Chicago, 1-23. 
